\title{
The Empirical Study on Stock Price Effect of Private Placement Announcement in China's Main Board Market
}

\author{
Menglu Zheng \\ Shanghai Baoshan District Shangda Road No.99 Shanghai University, China \\ 1006417879@qq.com
}

Keywords: Private placement; Event study; Abnormal return ratio; Stock price effect

\begin{abstract}
Since the split share structure reform, private placement has become an important mode of refinancing of listed companies in China. In this paper, based on the data in 2015, the event study method is used to study the effect of stock price on private placement. The results show that there is a significant positive stock price effect. And then put forward the corresponding policy recommendations, including providing valuable reference for China's market regulator to better guide the issuance of behavior and make private placement become more effective way of refinancing. Furthermore, this paper will also guide the investors to invest rationally and effectively.
\end{abstract}

\section{Introduction}

Private placement of new shares refers to the behavior of listed companies to raise funds through issuing shares to specific investor in a nonpublic way. With the achievement of the reform of the split share structure reform in May 8,2006, the refinancing function of the securities market has been restored. Since then, China's listed companies are very enthusiastic about the private placement, and private placement has become the main means of equity refinancing and acquisition of assets of listed companies. Besides, it also becomes a hot pursuit of investors.

\section{Research Methods and Models}

In the study of the impact of a specific event on the stock market, the event study method is widely used. Event study method has the following steps.

Determining the Event and Event Window Period. In this paper, the event refers to the announcement of private placement, and private placement plan announcement date as the base date. If the announcement date is non-trading day, it will be extended to one day as the base date. This paper defines the base date of the event is day 0 , day $t$ on behalf of $t$ days before the announcement and day $t$ on behalf of $t$ days after the announcement. This paper selects 7 trading days before and after the announcement. That is, $(-7,7)$ as the window period of the event.

Abnormal Return Ratio and Cumulative Abnormal Return Ratio. Abnormal return ratio is equal to the actual rate of return on the stock minus the normal rate of return. Generally speaking, there are market model, constant mean model, constant income model and market adjustment model for normal returns. Among these, market adjustment model has a very strong timing. The model assumes that each company in the event period, the normal return $\mathbf{R}_{\mathbf{i t}}$ per day is the same as the market return $\mathbf{R}_{\mathbf{m t}}$, that is, $\mathbf{E}\left(\mathbf{R}_{\mathbf{i t}}\right)=\mathbf{R}_{\mathbf{m t}}$.If the price fluctuation of a certain kind of securities is related to the price fluctuation of the market, the market adjustment model is more appropriate. Since the stock market of our country is a emerging market, the stock price fluctuates with the fluctuation of the whole market. This paper will choose market adjustment model for empirical research. At the same time, we need to draw the following data according to the model.

The abnormal return ratio of stock $i$ on day $t$ is as follows:

$$
\begin{aligned}
& R_{i t}=\ln P_{i t}-\ln P_{i t-1} \\
& R_{m t}=\ln \text { index }_{m t}-\ln \text { index }_{m t-1}
\end{aligned}
$$




$$
A R_{i t}=R_{i t}-R_{m t}
$$

$\mathrm{R}_{\mathrm{it}}$ refers to the actual rate of return of the sample stock $\mathrm{i}$ on day $t, \mathrm{R}_{\mathrm{mt}}$ refers to the market return on day $t, \mathrm{P}_{\mathrm{it}}$ expresses the stock $\mathrm{i}$ closing price on day $\mathrm{t}$, index $\mathrm{mt}_{\mathrm{t}}$ expresses the CSI 300 index closing point on day $t$.

The sample average abnormal return ratio $\mathrm{AAR}_{\mathrm{t}}$ formula is as follows $(\mathrm{N}$ is the total number of samples):

$$
A A R_{t}=\frac{1}{N} \sum_{i=1}^{N} A R_{i t}
$$

Sample cumulative abnormal return $\mathrm{CAR}_{\mathrm{i}}$ formula is as follows:

$$
\operatorname{CAR}_{i\left(t_{1}, t_{2}\right)}=\sum_{t_{1}}^{t_{2}} A R_{i t}
$$

Sample average cumulative abnormal rate of return CAR formula is as follows:

$$
\operatorname{CAR}_{\left(t_{1}, t_{2}\right)}=\frac{1}{N} \sum_{i=1}^{N} C A R_{i\left(t_{1}, t_{2}\right)}
$$

T Test for Abnormal Return Ratio. In the window period, $T$ test forAAR $\mathbf{R}_{\mathbf{t}}$ and $\mathbf{C A R}$, if the results are significantly different from 0 , indicating that the announcement has a significant impact on stock price volatility.

a.T test forAAR ${ }_{t}$ :

$\mathrm{H}_{0}: \mathrm{AAR}_{\mathrm{t}}=0, \mathrm{H}_{1}: \mathrm{AAR}_{\mathrm{t}} \neq 0$

The calculation of the mean and variance of abnormal return ratio on day $\mathrm{t}$ :

$$
\begin{aligned}
& A A R_{t}=\frac{1}{N} \sum_{i=1}^{N} A R_{i t} \\
& S^{2}\left(A A R_{t}\right)=\frac{1}{N-1} \sum_{i=1}^{N}\left(A R_{i t}-A A R_{t}\right)^{2} \\
& T=\frac{A A R_{t}}{S\left(A A R_{t}\right) / \sqrt{N}}
\end{aligned}
$$

b.T test for CAR:

$$
\mathrm{H}_{0}: \mathrm{CAR}_{\left(\mathrm{t}_{1}, \mathrm{t}_{2}\right)}=0, \mathrm{H}_{1}: \mathrm{CAR}_{\left(\mathrm{t}_{1}, \mathrm{t}_{2}\right)} \neq 0
$$

In the window period $\left(t_{1}, t_{2}\right)$, the cumulative average abnormal return ratio of the stock is calculated as follows:

$$
\begin{aligned}
& \operatorname{CAR}_{\left(t_{1}, t_{2}\right)}=\frac{1}{N} \sum_{i=1}^{N} C A R_{i\left(t_{1}, t_{2}\right)} \\
& S^{2}\left(C A R_{\left(t_{1}, t_{2}\right)}\right)=\frac{1}{N-1} \sum_{i=1}^{N}\left(C A R_{i\left(t_{1}, t_{2}\right)}-C A R_{\left(t_{1}, t_{2}\right)}\right)^{2} \\
& T=\frac{C A R_{\left(t_{1}, t_{2}\right)}}{S\left(C A R_{\left(t_{1}, t_{2}\right)}\right) / \sqrt{N}}
\end{aligned}
$$


Compares the $\mathrm{T}$ value of critical value in $10 \%, 5 \%$ and $1 \%$ level, if the inspection result is significant, reject the null hypothesis $\mathrm{H}_{0}$.It shows that the private placement does have influence on the stock price, vice versa.

\section{Empirical Test and Analysis}

Sample Selection. In this paper, several stocks of Shanghai and Shenzhen two main board markets in 2015 was selected as the research object, which involved many industries, such as construction, real estate, steel and so on. The sample is obtained by random selection in compliance with the following criteria:

1.Before and after the announcement of the issuance of the 7 trading days, the listed companies did not occur, such as annual reports, dividends, equity incentives, important contracts and other important matters to be announced.

2.Able to obtain complete financial data, stock transaction data and additional announcement information.

3.Not ST stock.

4.Non-financial stocks. Because the financial companies' profit model is very different from that of the manufacturing enterprises.

5.Before and after the announcement date, company did not suspend for long time.

6.During the time the company do a number of private placement, choose the first time one as a sample.

Empirical Testing and Analysis. To deal with the stock samples, calculate before and after the announcement date of 7 trading days of Sample Firms stock's abnormal return ratio and cumulative abnormal return ratio, and do a single sample $T$ test of the sequence to verify the $\mathrm{AAR}_{\mathrm{t}}$ and CAR are significantly different from zero. The average abnormal return ratio and cumulative average abnormal return ratio time series of the sample were made by EXCEL, and a single sample $\mathrm{T}$ test was performed with Eviews software. The results are shown in Fig. 1and Table 1. In order to clearly understand the impact of the announcement of private placement plan on the abnormal return ratio, this paper selects a few window period of the cumulative average abnormal return ratio for $\mathrm{T}$ test, the results are shown in Table 2.

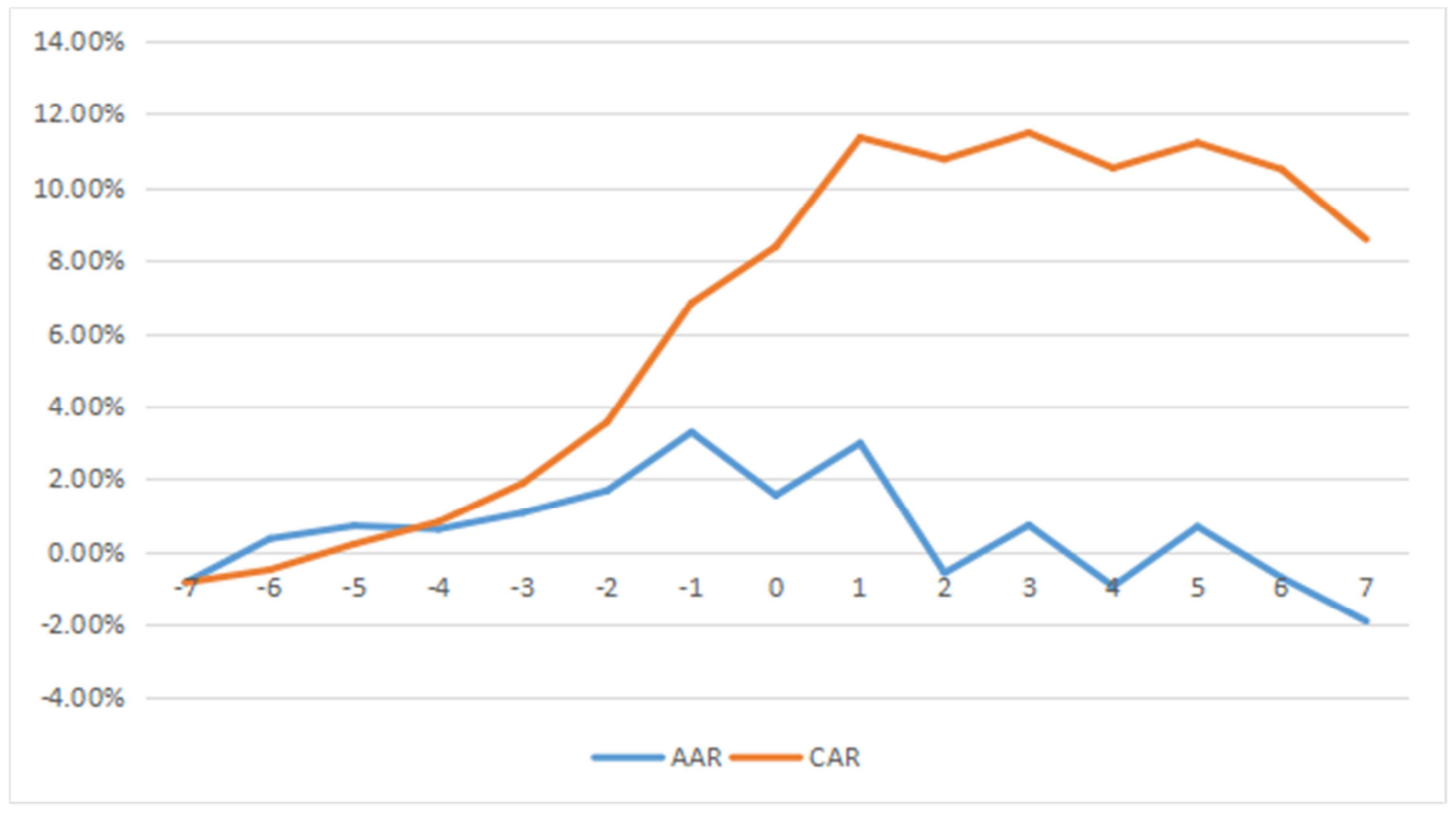

Figure 1. The average abnormal return ratio and cumulative average abnormal return ratio time series 
Table1T test table of the abnormal return ratio before and after the announcement day

\begin{tabular}{ccccc}
\hline time & $\mathrm{AAR}_{\mathrm{t}}(\%)$ & $\mathrm{T}$ value & $\mathrm{CAR}(\%)$ & $\mathrm{T}$ value \\
\hline-7 & -0.850 & -1.195 & -0.850 & -1.195 \\
-6 & 0.349 & 0.524 & -0.501 & -0.433 \\
-5 & 0.703 & 0.734 & 0.202 & 0.135 \\
-4 & 0.611 & 0.970 & 0.814 & 0.458 \\
-3 & $1.066^{*}$ & 1.264 & 1.879 & 0.950 \\
-2 & $1.678^{*}$ & 1.735 & $3.55^{*}$ & 1.603 \\
-1 & $3.279 * * *$ & 3.076 & $6.836^{* *}$ & 2.491 \\
0 & 1.547 & 0.951 & $8.383 * *$ & 2.333 \\
1 & $2.976^{* *}$ & 2.151 & $11.359 * * *$ & 4.418 \\
2 & -0.588 & -0.327 & $10.771 * * *$ & 4.751 \\
3 & 0.717 & 0.567 & $11.489 * * *$ & 4.089 \\
4 & -0.953 & 0.731 & $10.535^{* * *}$ & 3.562 \\
5 & 0.680 & 0.549 & $11.210^{* *}$ & 2.904 \\
6 & -0.717 & -0.460 & $10.498^{*}$ & 2.058 \\
7 & -1.916 & -1.247 & 8.581 & 1.564 \\
\hline
\end{tabular}

Table $2 \mathrm{~T}$ test table of CAR $(\mathrm{t} 1, \mathrm{t} 2)$ in different window period

\begin{tabular}{lll}
\hline Window period & CAR $(\%)$ & T value \\
\hline$\left(\begin{array}{ll}0,1 & 1\end{array}\right.$ & $4.522^{*}$ & 2.605 \\
$(-1,0)$ & $4.826^{* *}$ & 2.196 \\
$(-1,1)$ & $7.801^{* * *}$ & 4.036 \\
$(-3,2)$ & $9.958^{* * *}$ & 5.164 \\
$(-2,4)$ & $8.656^{* *}$ & 2.480 \\
$(-5,5)$ & $11.716^{* * *}$ & 3.283 \\
$(-7,7)$ & 8.581 & 1.564 \\
\hline
\end{tabular}

Note: $* * *, * * *$ are expressed at $10 \%, 5 \%$, and $1 \%$ levels the results are significant.

As shown in Fig. 1, 7 days before and after the private placement announcement date, the average abnormal return ratioAAR $\mathrm{t}_{\mathrm{t}}$ showed a trend of first increase and then decrease. In $(-7,-1)$ window period, $A A R_{t}$ gradually increases, every ratio of this period is positive except day -7 . This shows that the event is likely to have been leaked in advance. In day -1 , the average abnormal return ratio is the highest, which shows that market had the largest response on the day before the announcement date of the plan for the private placement. And in $(-1,7)$, the average abnormal return ratio declines in volatility, meanwhile the average abnormal return ratio is always positive until day 6 which ratio becomes negative. It means after the announcement, the market is still relatively optimistic about the issue of private placement, but the impact of the announcement on the stock price gradually reduced, and gradually close to the true value of the stock.

It can be seen from Table 1, the average abnormal return ratio of sixth days before the announcement date has been positive. In the 7 days before the announcement date, there is only one day that the average abnormal return ratio is negative. The positive average abnormal return ratio is mainly concentrated before day 1 , and the ratio of the day -1 is the largest which reached $3.279 \%$, and the $t$ test results are highly significant which means before the announcement the stock price already has significant positive effect. On the announcement day, the average abnormal return ratio has decreased significantly, and then showed a further decline in the trend. Similarly, the average cumulative abnormal return ratio also shows a clear trend. On day -5 the ratio begins to be positive and on day -2 the average cumulative abnormal return ratio begins to be a sharp rise, reaching $6.836 \%$ and is significantly positive at $5 \%$ level. Since the cumulative average abnormal return ratio is further increased, the highest point falls on day 3, then the ratio declines in volatility. Thus, investors have been holding shares to day 3 will get a huge return.

From Table 2 can be found that the average cumulative abnormal return ratio of $(0,1),(-1,0),(-1$, $1),(-3,2),(-2,4),(-5,5) 6$ window period are all significant in $10 \%$ level. After the announcement of private placement plan, the stock price performance increased significantly, indicating that the private placement has a positive effect on the stock price. With the extension of the time interval, the average cumulative abnormal return ratio has a tendency to increase, but in $(-7,7)$, the ratio has a significant decline, which shows that the private placement effect on stock prices has a strong timeliness. To a certain level, the farther away from the day of the announcement, the effect on the stock price is less obvious. 


\section{Empirical Conclusions}

There is a positive impact on the stock price of the listed companies in China's main board Market. The positive effect mainly concentrated in the $(-3,1)$ and before the announcement the stock price effect is most obvious. After the announcement, the average abnormal return ratio of the sample decreased. It is believed that insider trading, information disclosure and other reasons make the stock price has a positive effect in advance, and then after the announcement, this effect has been confirmed by positive expectations, and positive price effects gradually disappear. Overall, the private placement announcement can drive the stock price rise, and make the investors to obtain abnormal returns. However, the investors who bought the stock before the private placement announcement can get more abnormal return than the investors who bought the stock late.

\section{Policy Suggestion}

Strengthen Supervision. First, we must further improve the placement of relevant information disclosure system, and urge the relevant person to adopt the principle of fairness and justice to the disclosure of the private placement. Second, the sponsor should also actively fulfill its corresponding obligation of information disclosure, and strengthen the role of the third party supervision in the issuance process. Third, crack down on insider trading. Make the cost of insider trading far more than its revenue to reduce the possibility of insider trading.

Guide Rational Investment. On the one hand, regulators should crack down the illegal behavior of using private placement to manipulate the stock or mislead or deceive investors. On the other hand, regulators should introduce a number of policies to protect the investors, encouraging and guiding their rational investment. For example, sponsor agencies further disclose the relevant risks and establish multiple evaluation system to help small and medium investors comprehensive the behavior of private placement more accurately.

\section{References}

[1] Hertzel M, Smith R.L: Market Discounts and Shareholder Gains for Placing Equity Privately. Journal of Finance, 1993.

[2] H.F. Gu,D. Wu: Research on the Stock Price Effect of Private Placement Announcement in Chinese Listed Companies[J].Wuhan Finance Monthly,2014.(In Chinese)

[3] Z.Li:An empirical study on the announcement effect of private placement of Listed Companies in China and its influencing factors(Ph.D., University of International Business and Economics, China 2011). (In Chinese)

[4] X.X.Liu: An Empirical Study on the Stock Price Effect of Private Placement Announcement in Chinese A Stock Market(Ph.D., Southwestern University of Finance and Economics, China 2012).(In Chinese)

[5]Jensen. Controversy of Seasoned Equity Issuance: Analysis and Evidence. The Midland Corporate Finance Journa19Summer, 1986.

[6] Wrack K. H. Equity Ownership Concentration and Firm Value: Evidence from Private Equity Financings. Journal of Financial Economics, 1989,23:3-28.

[7] Barclay, Michael J., Clifford G Holderness and Denis P.Sheehan,2005,PrivatePlacements and managerial entrenchment, working paper, Boston College.

[8] Karen Hopper Wruck and YiLin WU, 2007,Closeness Counts: The Role of Relationships in Private Placements of Equity, Working Paper Series, SSRN

[9]Thomas J. Chemmanur, and Paolo Fulghieri,1999, A Theory of Going-Public Decision, The Review of Financial Studies Y01.12 No.2, 250. 270

[10] Hsieh \& Walkling(2001), Jim Hsieh and Ralph Walkling,2006,Journal of Banking and Finance $30, \mathrm{vOl} .30$,issue $9,2433-2469$ 